\title{
GEOELECTRIC EVALUATION OF SUBSURFACE CONTAMINATION AT A GAS AND SERVICE STATION, ALAGOINHAS, BA, BRAZIL
}

\author{
Rogério de Jesus Porciúncula and Olivar Antônio Lima de Lima
}

Recebido em 2 junho, 2011 / Aceito em 25 novembro, 2011

Received on June 2, 2011 / Accepted on November 25, 2011

\begin{abstract}
This work contains the results of geoelectrical soundings performed around the Lubrijau Gas and Service Station, in Alagoinhas County, Bahia State, Brazil. A total of 56 vertical electrical soundings (VES) were conducted along five parallel lines using a Schlumberger electrode array with a maximum AB/2 spacing of $300 \mathrm{~m}$. The aim was to define the structure of the Marizal-São Sebastião aquifer system found below the area, as well as to evaluate the status of eventual contamination, caused either by fuel leaks or improper sewage disposal practices. Data were interpreted as one-dimensional sounding curves and as two-dimensional resistivity sections using both public domain (RESIST 1.0 and RES1D) and commercial (RES2DINV) softwares. The interpreted results have shown that: (i) the groundwater flow under the area is directed from NW to SE; (ii) the static water table lies from 30 to $45 \mathrm{~m}$ in depth; (iii) the depth to the contact between the Marizal and São Sebastião formations exceed $45 \mathrm{~m}$; and (iv) there is a conductive plume $(\rho<300 \Omega . \mathrm{m})$ in the subsurface, outlined as an ellipsoidal body extending to SE, having a length of about $850 \mathrm{~m}$ and a width of $600 \mathrm{~m}$ along its maximum spread. This plume has not yet reached the water well situated about $550 \mathrm{~m}$ from the gas station.
\end{abstract}

Keywords: hydrogeology, geoelectrical methods, Marizal-São Sebastião aquifer system, contamination plume.

RESUMO. Este trabalho contém os resultados de sondagens geoelétricas realizadas no entorno do Posto de Combustíveis e Serviços Lubrijau, município de Alagoinhas, Bahia. Foram realizadas um total de 56 sondagens elétricas verticais (SEVs) distribuídas ao longo de cinco linhas paralelas usando 0 arranjo de eletrodos Schlumberger com espaçamentos máximos de AB/2 igual a $300 \mathrm{~m}$. Seus objetivos foram definir a estrutura do sistema aquífero Marizal-São Sebastião sob a área, avaliar o estado de eventuais contaminações oriundas das atividades do posto causadas por vazamentos de combustíveis ou práticas inadequadas de disposição de esgotos. Os dados permitiram construir curvas unidimensionais invertidas e seções bidimensionais de resistividade, usando sottwares de domínio público (RESIST 1.0 e RES1D) e comercial (RES2DINV). Os resultados interpretados revelam que: (i) o fluxo subterrâneo está direcionado de NW para SE; (ii) o nível estático está a cerca de 30 a $45 \mathrm{~m}$ de profundidade; (iii) 0 contato entre as Formações Marizal e São Sebastião é superior a $45 \mathrm{~m}$ de profundidade; e (iv) há uma pluma condutiva $(\rho<300 \Omega$.m) em subsuperfície, delineada como um corpo elipsoidal estendido e inclinado para SE, com comprimento de cerca de $850 \mathrm{~m}$ e largura de $600 \mathrm{~m}$ em sua máxima abertura. Esta pluma ainda não atinge o poço de produção situado a aproximadamente $550 \mathrm{~m}$ de distância do posto.

Palavras-chave: hidrogeologia, método geoelétrico, sistema aquífero Marizal-São Sebastião, pluma de contaminação. 


\section{INTRODUCTION}

The problems relating environmental contamination and hydric resources are discussed by several scientists and researchers from different specialities. Scientific methodologies have been increasingly employed to evaluate the hydrogeological environment, producing information that helps to rationalize the use of such hydric resources. Geophysics comes as a very useful science for the hydrogeological description and evaluation of the subsurface due to its sensitivity to subtle variations of the physical properties of the geological materials. The resistivity method, besides being non-invasive, is very effective in geo-environmental studies, due to the observable differences in the electrical properties of a wide variety of fluid contaminants. Its applicability is well shown in Lima et al. (1995), Sauck et al. (1998), Atekwana et al. (2000) and Porsani et al. (2004).

The county and city of Alagoinhas are located above one of the best aquifers in the Bahia State, the São Sebastião aquifer. The aquifer is a reservoir with a high potential to supply good quality of fresh water and it occupies an area of 7,000 sq. $\mathrm{km}$, equivalent to two thirds of the area of the Recôncavo Basin. All water used to attend the needs of the population, farming, and industries of the county is extracted from this aquifer.

Gas and service stations are considered to be potential pollution sources affecting the soil, the subsoil and water bodies, both in the surface and underground, according to CONAMA Resolution \#273, issued in 2000, that established the guidelines for environmental licensing of such commercial enterprises. The reasons for possible subsurface contamination caused by the activities performed at gas and service stations are indiscriminate sewage dumping and accidental fuel spill during the fuel transfer operation from the truck to the tank or by cracks and corrosion at the tanks' structure, by spills from connections or even by inadequate facilities.

Sewage dumping is among the main causes for the contamination of underground water reservoirs. Sewage is discharged by several ways on or under the soil surface. In rural zones where sewage systems are not available, people usually use septic tanks and drain holes. Such systems constitute a simple and cheap way to dispose of residual water but they threaten soil and aquifer quality (Manoel Filho, 2008).

Contaminants that originate from spills in gas station tanks, usually of gasoline and Diesel oil, occur as liquid phase nonaqueous compounds (NAPLs) that when in contact with the geological environment, initially, cause an increase in the soil and subsoil resistivity. However, as time goes by, the action of microorganisms helps the biodegradation of the hydrocarbon molecules, creating acids that make the environment even more conductive (Sauck et al., 1998). Such contaminants may occur in phases of vapor, adsorbed, dissolved in water and/or as a free phase floating over the water, and their geoelectrical responses can be of either high or low resistivity, depending on their time of residence in the terrain and their exposition to degradation processes.

The presence of a water well in a contaminated aquifer disturbs the dynamics of the groundwater flow and can accelerate contaminant dispersion in the hydrogeological environment and possibly distribute such contaminants through the water main, seriously threatening the health of the local population. Thus, it is necessary to increase our knowledge of the hydric resources taking into account the several agents that can impact that environment by conducting a multidisciplinary study aiming to develop scientific knowledge in a way that we can produce information and materials that may be used to improve understanding of the local hydrogeology and to increase the life quality of the population.

\section{CHARACTERIZATION OF THE STUDY AREA}

The region where the geophysical study was conducted corresponds to the area around the gas station called Posto de Combustíveis e Serviços Lubrijau (yellow rectangle shown in Fig. 1), which used to be called Posto Alagoinhas, located at Km 103 of the BR 101 highway, Sauípe Industrial District (DISAI), 7 km far from downtown Alagoinhas, between Alagoinhas and Entre Rios cities. That gas station presents very intense activity, both in attendance to heavy vehicles, as in the use of their bathroom and toilets facilities.

Near to the gas station there is a leather salting unit in operation (blue rectangle shown in Fig. 1), located NE of the gas station, where crude leather from bovine cattle is manufactured. According to the local population that salting unit operates for a tannery company named BRESPEL. This company is partially responsible for the production of a major contamination plume caused by the poor treatment of its effluents in the Espuma District, approximately $4 \mathrm{~km} \mathrm{NE}$ of the area of this study. That plume was identified and measured by a detailed geophysical study conducted by Pereira \& Lima (2007). The inhabitants of the area are worried about the operation of the salting unit due to bad odours emanated and to the indiscriminate dumping of their wastes.

Besides those environmental impacting agents the city's domestic and sanitary sewage are disposed at septic tanks and drain holes. A water extraction well (red circle shown in Fig. 1) from which water is distributed through a water main of approximately $19.5 \mathrm{~km}$ long for the population of the city and surround- 


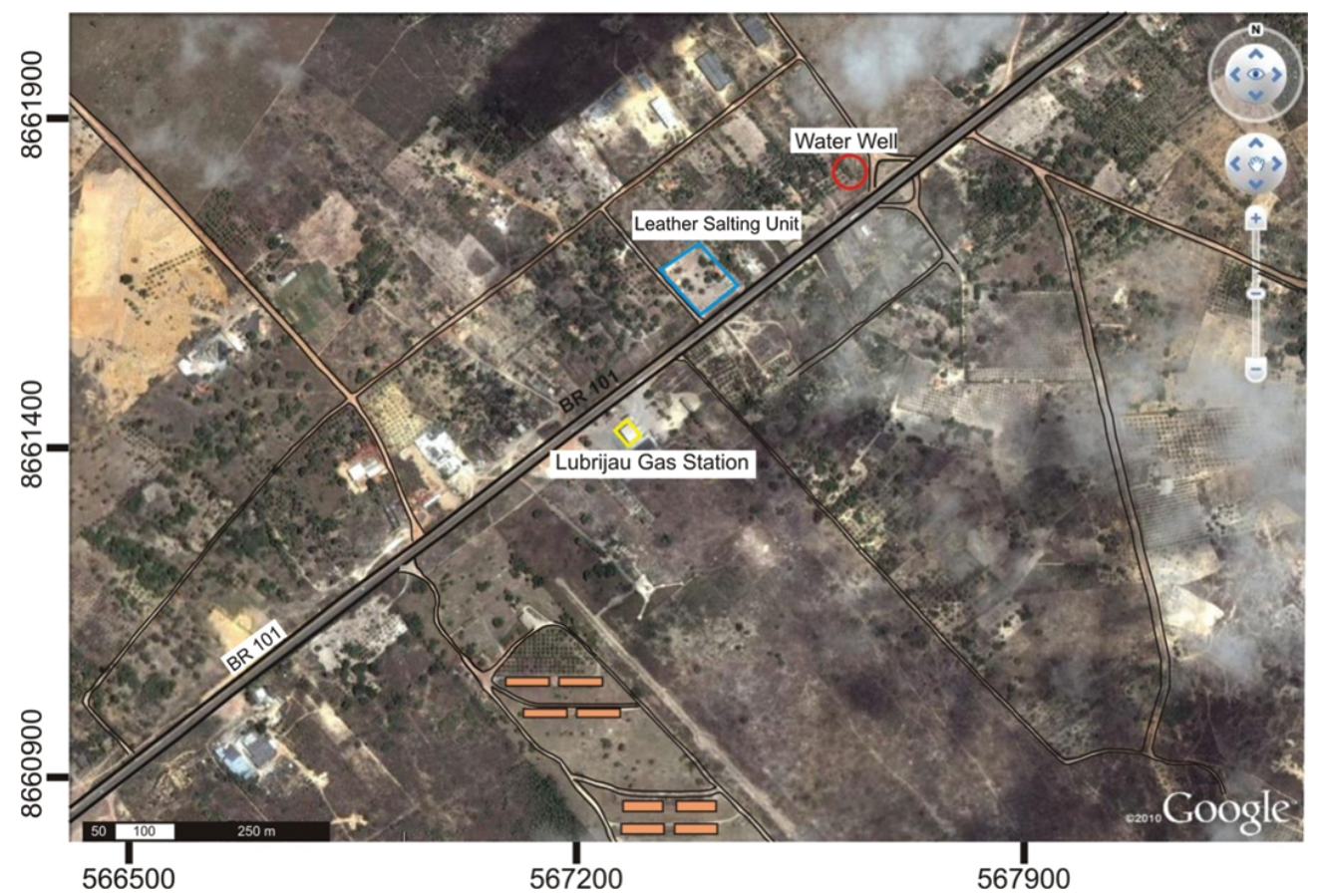

Figure 1 - Image of the study area (based on Google Earth, 2010).

ings, for cattle raising, agricultural and industrial uses. The water well is operated by SAAE (Serviço Autônomo de Água e Esgoto de Alagoinhas) and is located some $300 \mathrm{~m}$ far from the salting unit and $550 \mathrm{~m}$ from the gas station, as shown in Figure 1. The water pumping at this well affects the hydric flow conditions of the aquifer and may accelerate the migration of possible contaminants. Thus, the disposition of the contaminants directly into the water main harms the population's health and affects its life quality.

As for the geological characterization of the study area, Alagoinhas County is inserted in the Northern Recôncavo sedimentary basin, which corresponds to an aborted rift related to the fragmentation of the Gondwana continent. The sedimentary cover of the region is basically composed of sediments belonging to the Quaternary Units and to the Barreiras, Marizal and São Sebastião formations (Fig. 2). However, the local cover is mainly composed of Marizal Formation sediments deposited, over an erosional unconformity with the São Sebastião Formation sediments. The Marizal Formation sediments are coarse sandstone with medium to large cross stratifications, yellowish to reddish, and intercalated conglomerates with quartz grains and rock fragments. The São Sebastião Formation is composed of coarse sandstone with medium to large size cross stratifications, yellowish to reddish, and intercalated quartz granules and rock fragments (Ghignone, 1979).
In accordance with physical-chemical and bacteriologic studies done by Nascimento (2005), Alagoinhas County has one of the best aquifer systems of the Bahia State, both in quality and volume of water, being the best the upper Marizal-São Sebastião aquifer system. The groundwater reserves represent approximately $6 \%$ to $7 \%$ of the total Recôncavo Baiano volume and the present county's consumption is less than $20 \%$ of the aquifer's potential. The Marizal-São Sebastião aquifer system presents two coupled components: a free or water table component, represented by the Marizal Formation, eventually covered by the Barreiras sediments and by the upper sandy part of the São Sebastião Formation, and a semi-confined or artesian component, represented by the sandstone packages totally contained in the São Sebastião Formation (Lima, 1999).

Porciúncula (2007), based on geoelectrical data, established a regional structural model of the aquifer, with which was possible to identify the underground presence of two aquifer intervals possibly separated by a shale bed, containing intercalated siltstone and sandstone in variable proportions.

In Alagoinhas County the groundwater flow of the MarizalSão Sebastião system accompanies the surface drainage dominated by the flow of the Catu and Sauípe rivers. In the urban zone the flow follows the Recôncavo Baiano pattern, from NW to SE, in the Catu river basin. However, in the northeastern region, going towards Entre Rios County, the groundwater flow is controlled by 


\section{GEOLOGIC MAP OF ALAGOINHAS COUNTY}

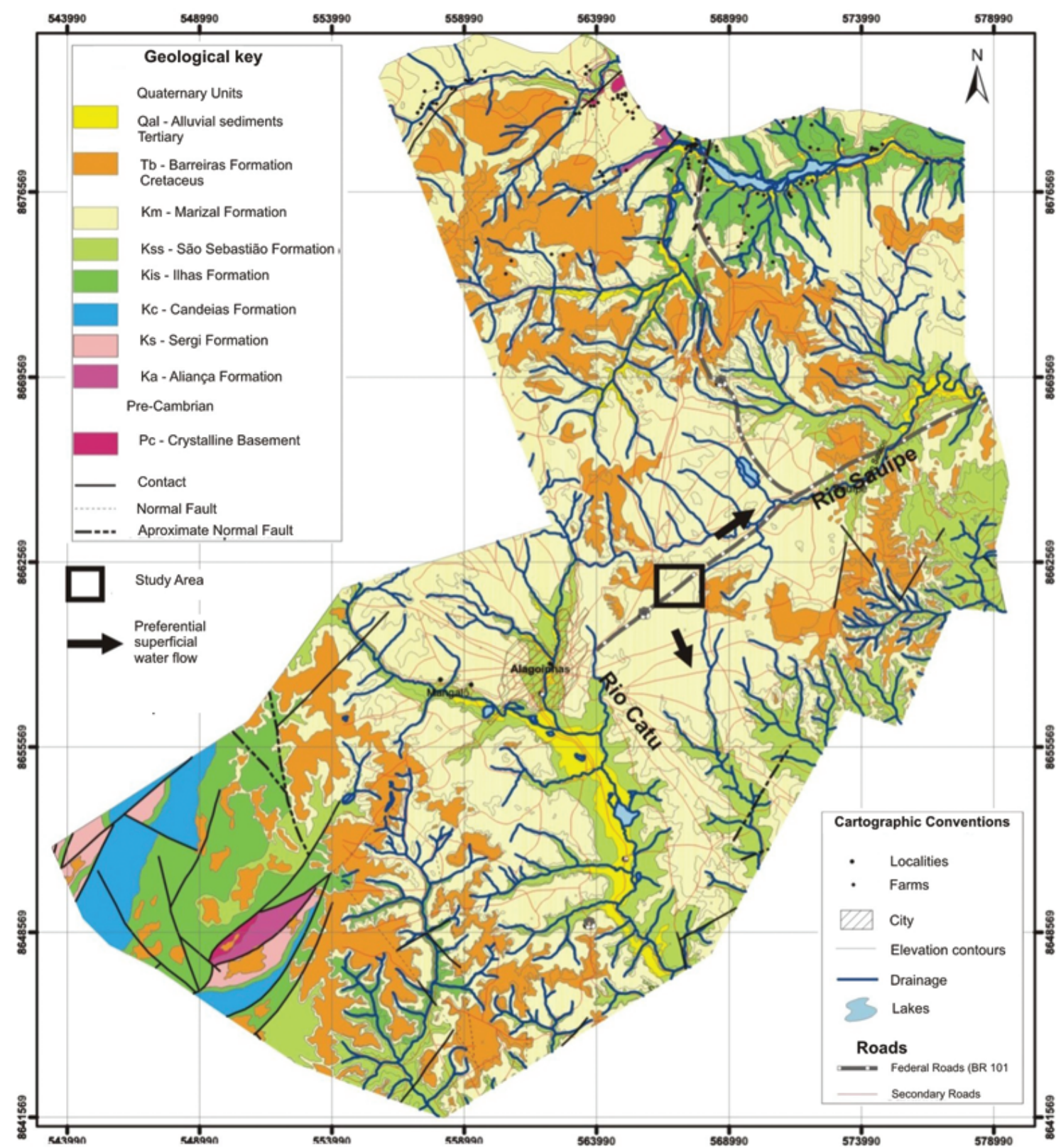

Figure 2 - Geologic map of Alagoinhas County showing the location of the study area (based on Porciúncula, 2007).

the Sauípe river basin flow. Figure 2 shows that the study area, highlighted in the map, is located between those two superficial flow systems. Therefore, one of the objectives of this paper is to collect information to define to which of those two systems the groundwater flow in the study area belongs. Since there is a well for groundwater supply in the area, this kind of information is of crucial importance for the understanding and protection of the local hydrogeological system.

\section{METHODOLOGY}

The geoelectrical resistivity method aims to identify variations of resistivity in the subsurface geological environments (Koefoed, 1979). It presents a broad spectrum of applicability and can be of interest for several fields of scientific studies in special for hydrogeology projects to investigate the depth of the saturated zone, to map contamination plumes, to locate recovering and production 
wells, to determine direction of underground flows, the possible intrusion of salt water and to map faults and fractures.

This method consists of introducing, via an artificial source and two electrodes ( $A$ and $B$ ), an electrical current into the soil. The difference of electric potential generated by the introduced current is measured by two other electrodes ( $\mathrm{M}$ and $\mathrm{N}$ ) placed near the current flow. Thus, as shown in Telford et al. (1990), it is possible to determine the apparent subsurface resistivity by using:

$$
\rho=K \frac{\Delta V}{I},
$$

in which

$$
K=2 \pi\left[\left(\frac{1}{A M}-\frac{1}{B M}\right)-\left(\frac{1}{A N}-\frac{1}{B N}\right)\right]^{-1}
$$

is the geometric factor that depends on the electrode array; $I$ is the injected electrical current and $\Delta V$ is the difference of electric potential between electrodes $M$ and $N$. The way the electrodes are placed and moved over the terrain during acquisition characterizes the technique employed in the field survey. Usually, the method employed in electrical resistivity surveys encompasses Vertical Electrical Soundings (VES) and Electrical Profiling (EP) techniques. The first technique aims at one-dimension determining the apparent vertical resistivity variation of geologic layers. The second technique is used to investigate the apparent lateral variation of the resistivity in the subsurface.

This study used the vertical electrical soundings technique employing a Schlumberger electrode array. The use of this technique requires that the potential measuring electrodes be fixed while the current injection electrodes are gradually separated. The depth reached by the survey increases in accordance with the increment in the distance between the current electrodes. The mathematical expression for the apparent resistivity of the Schlumberger array is given by:

$$
\rho_{a}=\pi\left[\frac{a^{2}}{b}-\frac{b}{4}\right] \frac{\Delta V}{I},
$$

in which $a=A B / 2$ and $b=M N$.

\section{DATA ACQUISITION AND PROCESSING}

The geoelectric data acquisition campaign was conducted during two field visits occurred in October 2009 and February 2010. Data were collected by using the vertical electrical soundings technique, employing a Schlumberger electrode array with a maximum spacing of 600 meters between the current electrodes (or $A B / 2=300 \mathrm{~m}$ ), obeying an aligned multiple electrical soundings configuration (Fig. 3).
In order to produce rectangular grids to be able to establish 3D models of the geoelectric distribution the 56 vertical electrical soundings (VESs) were performed by following five geoelectrical sounding lines (GS) parallel to the BR-101 highway as shown on Figure 3. The center of the VESs was determined in UTM coordinates using a GPS device and SAD-69 datum.

The equipment used to acquire geoelectric data was a SYSCAL R2 resistivity meter made by Iris Instruments (France), owned by CPGG/UFBA. Such equipment can be configured to register simultaneously apparent resistivity and chargeability. The equipment is divided in two units, one being the electrical current transmitter and the other the electric potential receiver.

A 12 volt battery served as source along with a $250 \mathrm{~W}$ DCDC converter that outputs up to 800 volt. Cables, reels and steel electrodes also composed the array of devices used at the field.

The electrodes were positioned in the ground by two field helpers in accordance with instructions transmitted via radio by the SYSCAL operator.

A solution of sodium chloride in water was applied in the region where the electrodes were inserted in the soil to reduce contact resistance, so that a stronger current flow could be injected into the terrain being investigated.

Apparent resistivity data were acquired through the average of 10 measurements, by employing switched square wave DC over a period of 2 seconds. Data were registered in the SYSCAL memory, written on tables and plotted in a bi-logarithm graph of $\rho_{a}$ (apparent resistivity) as a function of the $A B / 2$ spacing, allowing for an on-site control of data quality and of the degree of smoothing of the curve.

Theoretically, when a Schlumberger electrode array is used, the spacing between the potential electrodes is considered to be constant, while the distance between current electrodes is increased. In the field it can be observed that the electric potential is strongly reduced when the distance to the current electrodes is increased. Therefore, in order to deal with signal reduction, in some of the $A B / 2$ intervals the distance between potential electrodes was increased aiming a better signal/noise ratio. That procedure is controlled by a system called clutch.

The 56 acquired sounding curves were smoothed and error reduction procedures were applied to increase the reliability of data interpretation. In some VESs sets of curves of the same MN they had to be moved because they had been displaced by the action of variations of the lateral resistivity which occur when there are changes in the clutch. It was also necessary to interpolate or discard outlets.

Acquired data were processed using specific geophysical software. Apparent resistivity isocontour maps and sections were 


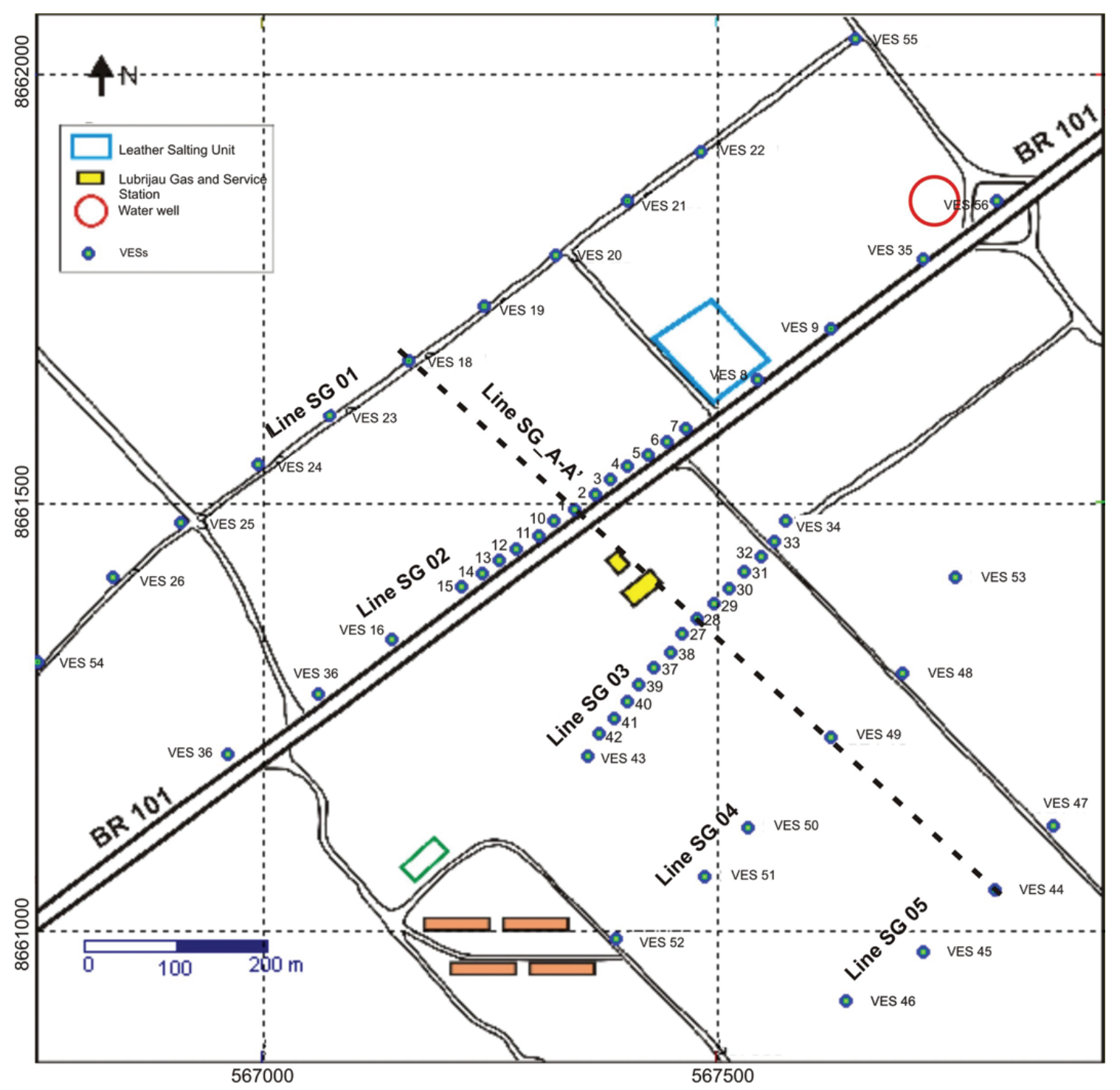

Figure 3 - Situation map of the study area showing the centers of the VESs.

produced using SURFER 8.0, an interpolation program made by Golden Software. For the one-dimensional inversions programs RES1D and RESIST 1.0 were used in sequence, taking as an initial model for RESIST 1.0 the estimates that had been made on the number, thickness and resistivity of the layers obtained with RES1D software via an automatic inversion. Under that option RES1D generates an inverted model with the same number of layers to VES points. By combining resistivity layers that are near to each other the interpretation program builds an initial inversion model for the RESIST 1.0, with the best inversion convergence. The $2 \mathrm{D}$ inversions were generated by the RES2DINV package, results being saved in the XYZ format and later interpolated by kriging, using SURFER 8.0 .
RESIST 1.0 is a data inversion program developed by Vander Velpen from Delft University. The program interactively adjusts a model composed of $n$ parallel flat layers until it reaches a value of mean square deviation between apparent resistivity valued of the theoretical and the field measurements. RES1D is a freeware, produced by GEOTOMO Software, used to develop direct and inverse models of electrical soundings. The direct model is constructed by using the linear filtering method, while the inverse model results from the application of the least squares optimization method (Loke, 2001). The RES2DINV, also developed by GEOTOMO, performs the 2D inversion of resistivity and induced polarization (IP), which is based on the smoothness-constrained least-square method (Geotomo, 2010). 


\section{RESULTS}

Figure 4 shows three maps of the apparent resistivity function generated with $A B / 2$ spacing of 5,40 and 300 meters, used to outline anomalies from superficial intervals to depths below the static level of the aquifer. Such maps enable the qualitative evaluation of resistivity lateral variations in the terrain, both in the vadose (or aerated) zone and in the saturated zone. It is estimated that the depth of the investigation is around $(A B / 4)$.

Interpretation based on such maps show that:
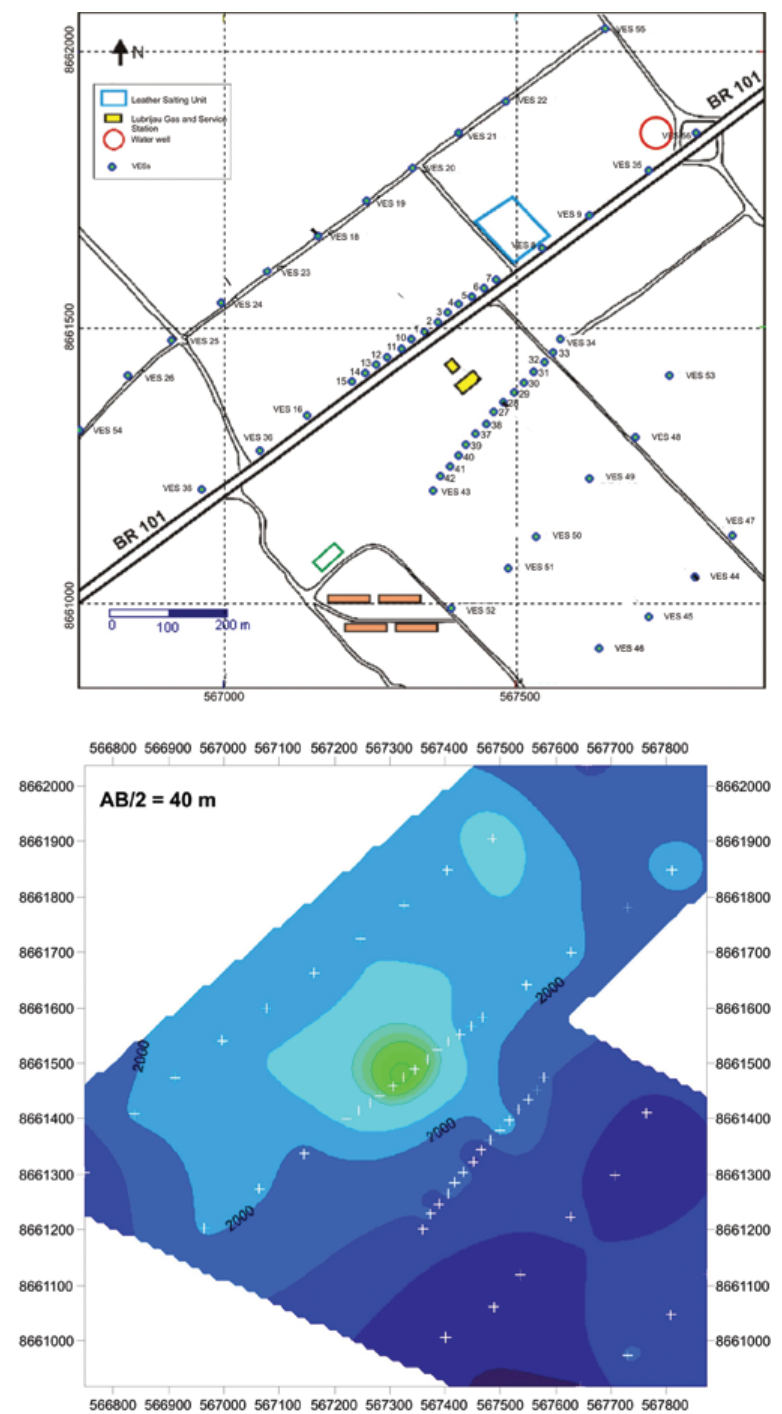

Apparent resitivity (ohm.m) (i) in the soil zone closer to the surface (map $A B / 2=$ $5 \mathrm{~m}$ ) there are two conductive anomalies elongated in the SW-NE direction and diagonally located. One of them underlies the gas station (shown in the center of the map) and the other is located under the region of the salting unit (shown in the upper right section of the map);

(ii) for $A B / 2=40 m$, the salting unit conductive anomaly becomes negligible, but the anomaly underlining the gas station persists;
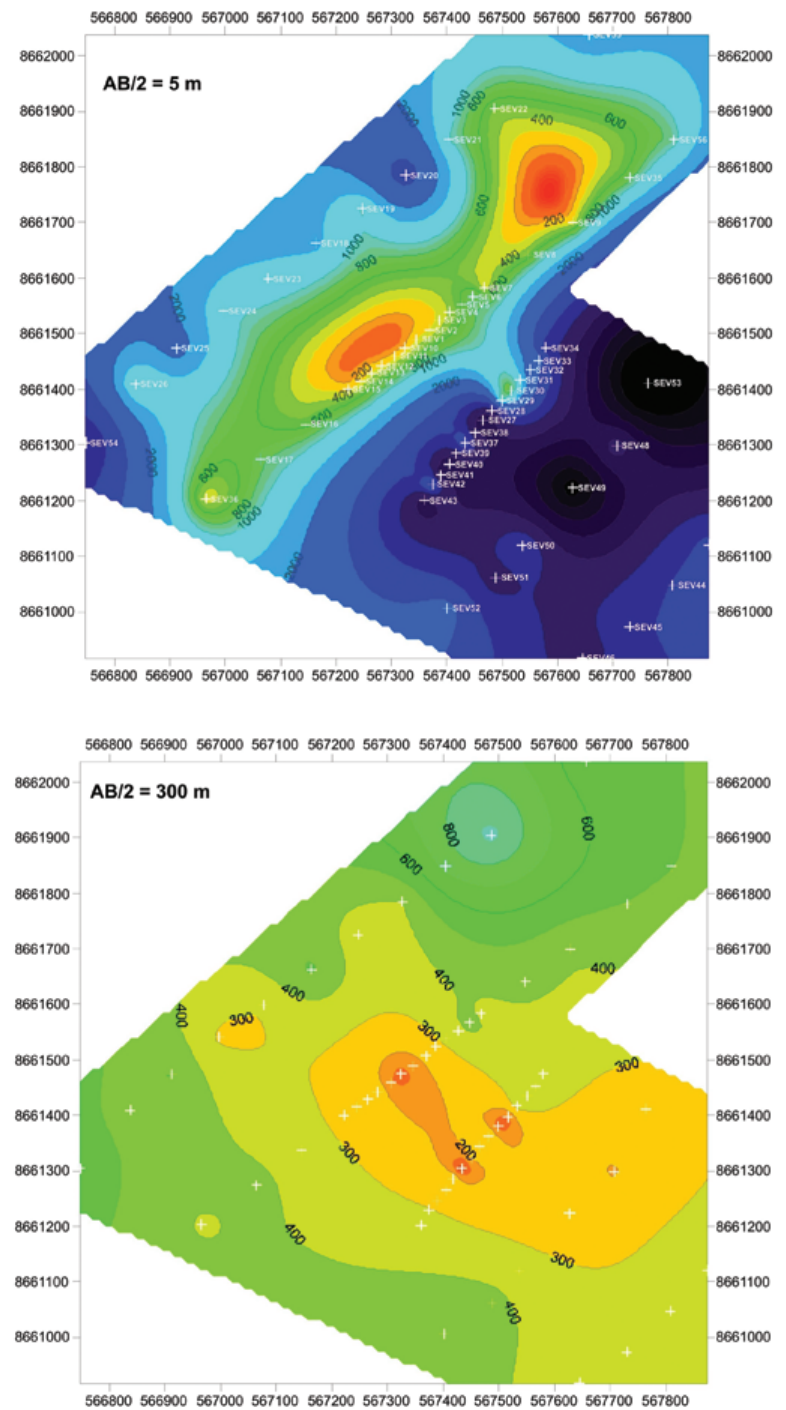

566800566900567000567100567200567300567400567500567600567700567800

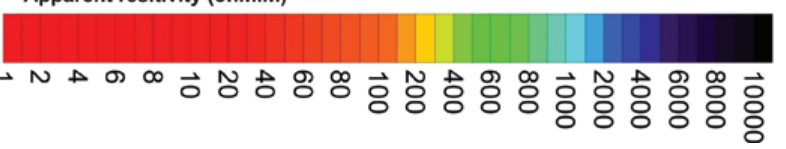

Figure 4 - Apparent resistivity maps of the study area. 
(iii) with $\mathrm{AB} / 2=300 \mathrm{~m}$, already below the aquifer's phreatic level, resistivity readings fall sharply and the anomaly under the gas station shows a NW-SE direction, the same direction as that of the assumed underground flow.

The sequence reveals how the infiltration of rain water occurs, how the vertical transport of contaminants inside the vadose zone happens and how such contaminants are spread by the underground flow, both longitudinally and transversally. Furthermore, the irregularities observed are probably due to the petrophysical heterogeneity of the sandstone at the Marizal and São Sebastião formations and also to the presence of fractures and faults in the latter formation.

Figure 5 shows three examples of vertical electrical soundings conducted in the area. The curves related to VES 2 and 36 on Line SG02 show a great similarity in vertical lithological variation patterns among the regions where they were conducted. On the other hand, they also show a strong difference between maximum amplitudes of the apparent resistivity values. The first VES, located closer to the gas station, shows much lower apparent resistivity values due to the interference of the contamination source (the gas station). The second one presents larger apparent resistivity values for being farther from that source. Curve VES 46 shows a pattern that is slightly different from that of VES 2 and 36. Its initial portion indicates lithological variations in the upper layers of the column. In general, the results of the one-dimensional inversions allow for distinguishing diverse geoelectric facies and defining the depth of the saturated zone, as well as the vertical lithological variations along with their depths and resistivity.

In Figure 6, the final models adjusted for the VESs of Line SG02 were plotted as a transverse section to obtain, as a first approximation, a structural model for the phreatic aquifer component in the study area. That section clearly shows the mapped position of the static level of the aquifer (traced blue line) as well as the position of the contact between Marizal (in yellow) and São Sebastião (in green) formations, besides the presence of a thin superficial layer, directly linked to the activities on the surface, interpreted as the soil region containing the larger proportion of clay. Besides the observed characteristics the section shows higher conductivity regions, highlighted by resistivity values in red, interpreted as contaminant movement zones. In the center of the section, such anomalies occur both in the non-saturated zone as in the saturated zone and relate to the contamination plume that originates at the gas and service station. On section SG02, in the region centered on VES 9 in its shallowest interval, it can be observed a superficial anomaly that seems to reflect a localized influence of the salting unit.

Figures 7 and 8 present the results of the $2 \mathrm{D}$ inversions of the sections corresponding to lines SG02 and SG_A-A', respectively. Each of them exhibits three sections. The first section represents the observed apparent resistivity, the second section the computed apparent resistivity and the third the adjusted resistivity model that describes the actual subsurface vertical and horizontal resistivity distribution. The number of iterations and the adjustment error are shown in the upper right corner of the figures. The final true resistivity sections roughly show two distinct hydrogeological horizons in the subsurface:

(i) the upper horizon corresponds to a thick interval, relatively more resistive (represented by blue colors), associated to the aeration zone (non-saturated zone), dominantly composed of clayish sandstone of the Marizal Formation;

(ii) the lower horizon corresponds to a relatively more conductive interval (shown in green and cyan) and is associated with the saturated zone of the Marizal-São Sebastião aquifer system. Such horizons also show the presence at the aquifer region of an extensive conductive anomaly (shown in red and yellow), characterized by true resistivity values below $300 \Omega . m$.

This anomaly represents the contamination plume derived from the activities at the Lubrijau Gas and Service Station. In the upper part of the last sections, a thin soil layer shows strong lateral resistivity variation. Lateral heterogeneities can also be observed in the aquifer's vadose zone. The static level of the aquifer appears as a high resistivity discontinuity (from approximately $6,000 / 8,000 \Omega . m$ to $1,500 \Omega$.m). It is tentatively shown in the figures as the $1500 \Omega . m$. isocontour. The conductive plume, some 600 meters wide and 850 meters in length, appears as an ellipsoidal body dipping towards the Southeast and can be identified from the depth of 40 meters to below the surveyed depth of 110 meters. From that it can be inferred that the general direction of the hydric flow in the area is from NW towards SE.

\section{CONCLUSIONS}

The survey results allowed, even if under the limitations of the used methodology to image the behaviour and characteristics of the non-saturated and saturated zones of the Marizal-São Sebastião aquifer system.

The depth of the static level mapped by electrical soundings varies from 30 to 40 meters. The water table and the direction of the underground flow both follow a NW-SE direction with some locally variations. 

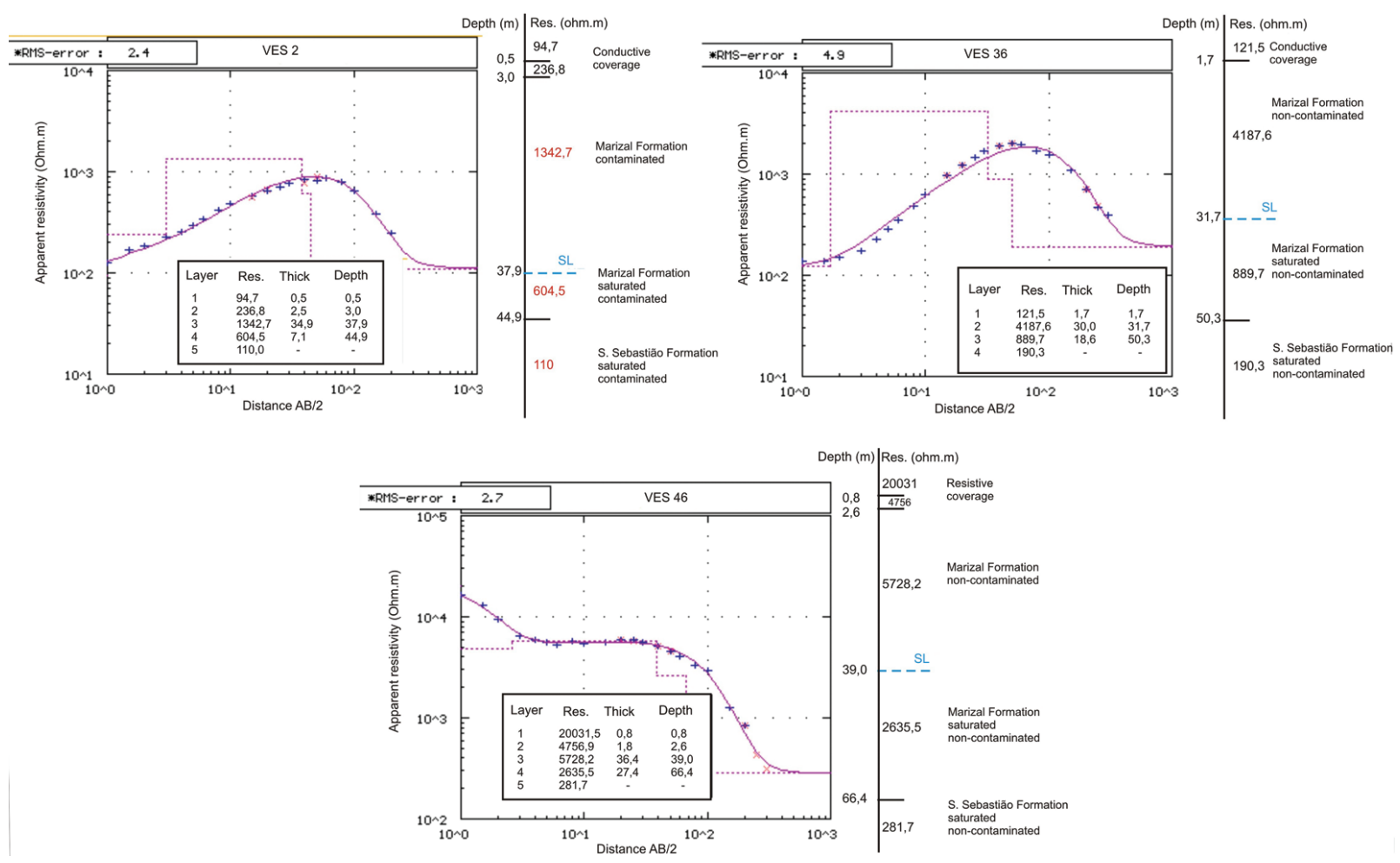

Figure 5 - Examples of the area's inverted vertical electrical soundings.

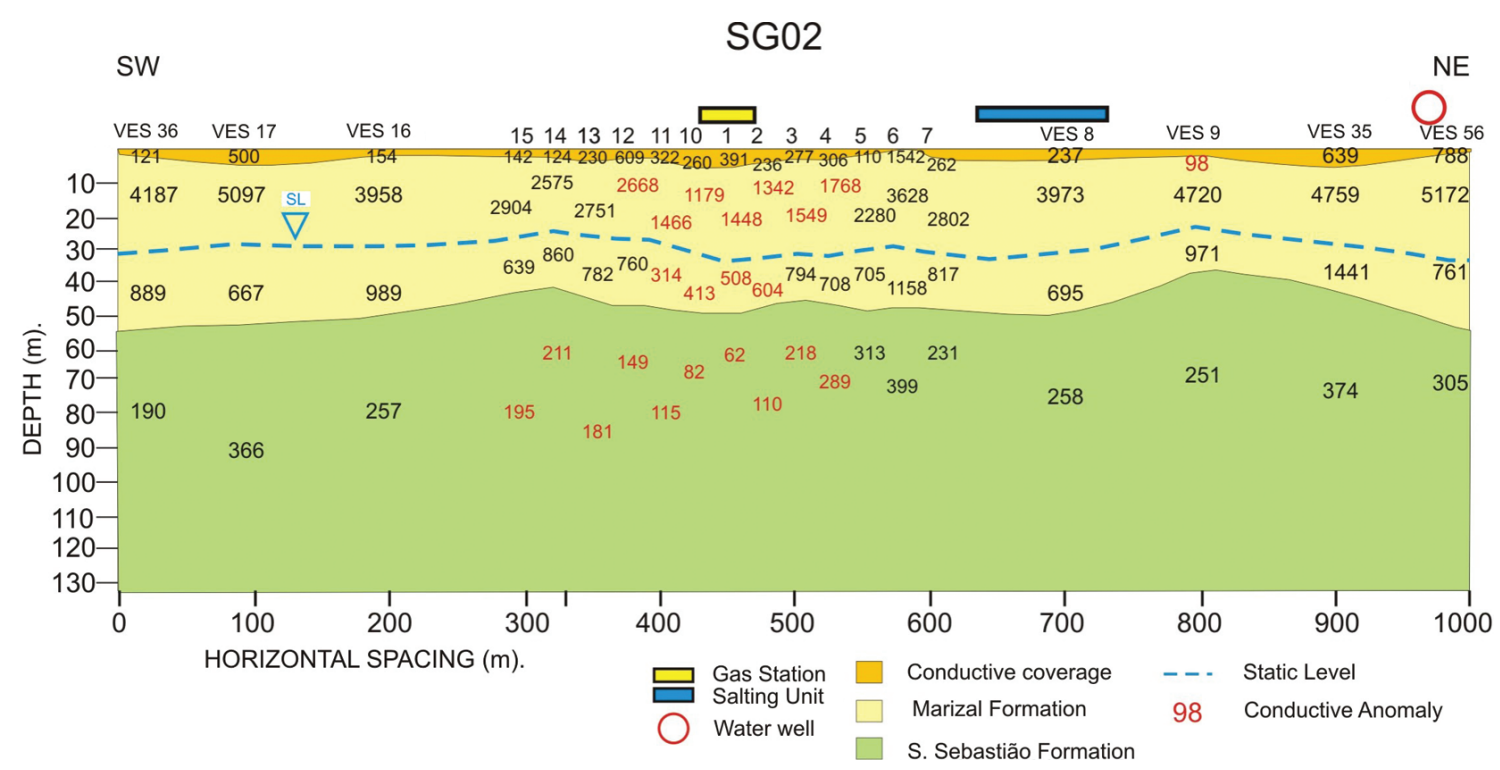

Figure 6 - Geoelectrical section developed based on one-dimensional VESs inversions of Line SG02.

The geoelectrical results considered as a space form allowed the identification of two zones marked by conductive anomalies, one near the salting unit and the other near to the gas station, both characterized as probable contamination sources. The first one is limited to the shallow portions and seems related to the activities performed at the salting unit. The second one has a vast vertical continuity and spreads from the non-saturated zone to the saturated zone, possibly associated with older fuel leaks 


\section{Line SG 02}

Pseudo-section of observed apparent resistivity SW

Iteration $=7$, error $=1.91 \%$

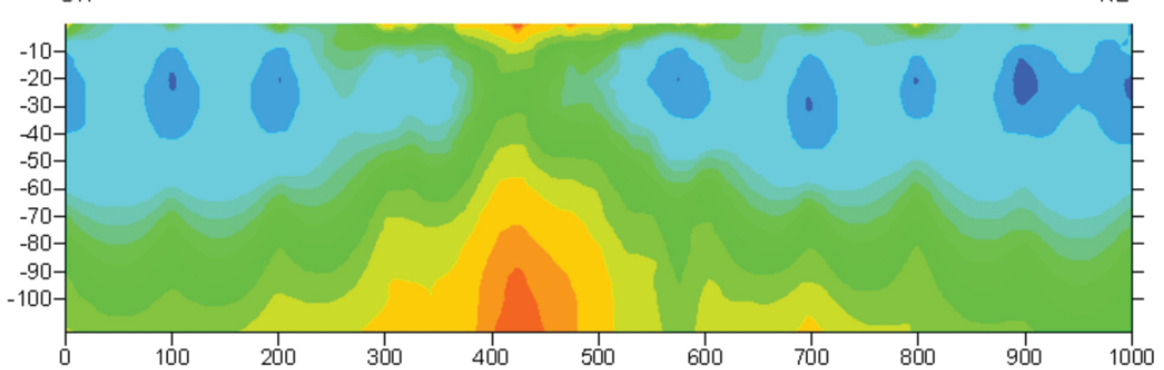

Pseudo-section of computed apparent resistivity
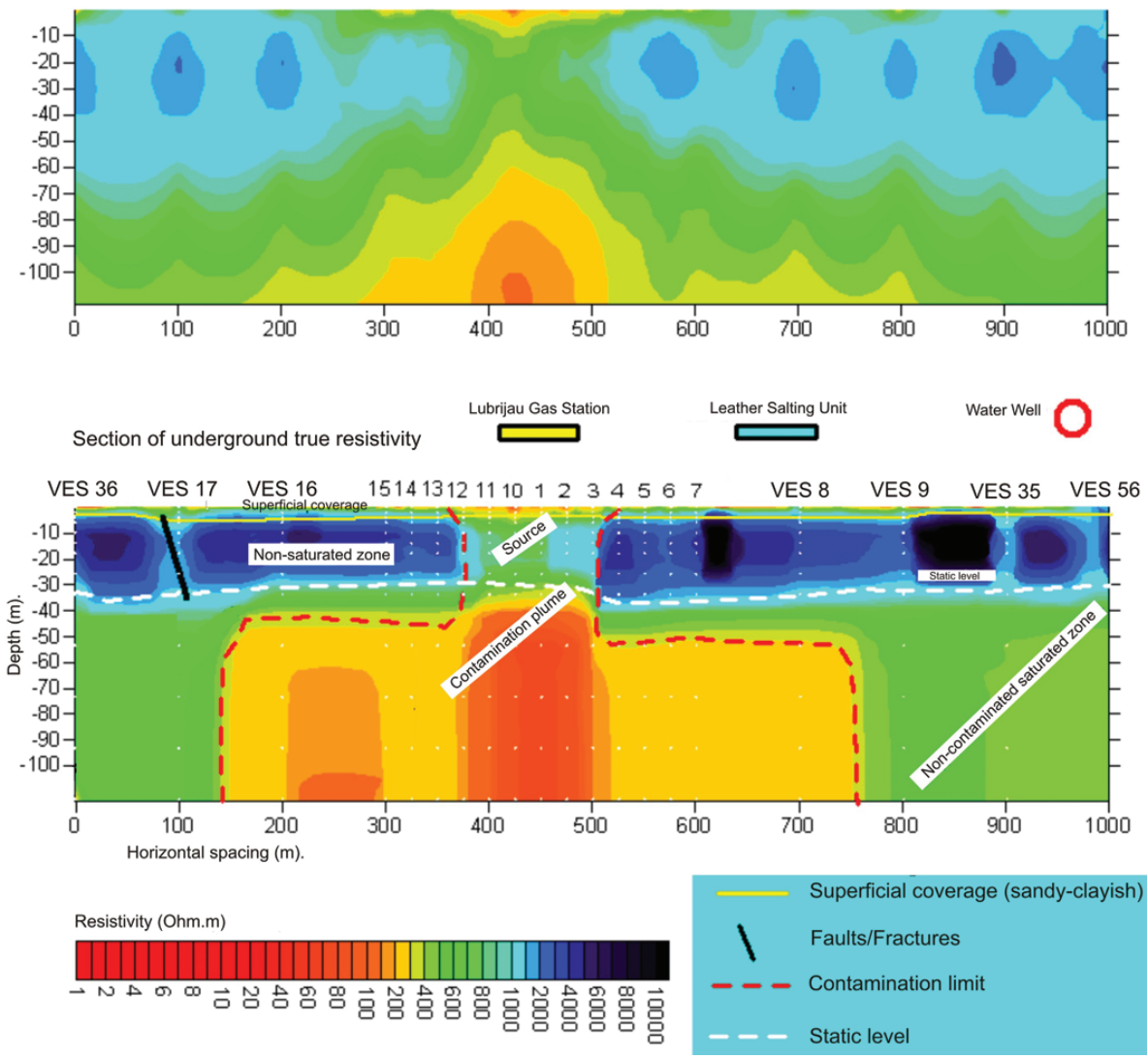

Figure 7 - Results of the 2D inversion of Line SG02.

from underground tanks or with inappropriate discharge of gas station sewage. The resistivity tests were fundamental in the effort to outline and evaluate the contamination plume in subsurface. In simple terms, the plume is characterized as an ellipsoidal body, dipping towards the NW-SE direction, with a maximum length of 850 meters and maximum width of 600 meters, extending vertically in the saturated zone down to depths below 110 meters.

The intensity of the contamination and the nature of the contaminants in the outlined conductive anomalies need to be evaluated through direct measure of physical and chemical parameters of the soil and the groundwater. Even though results indicate that the plume has not yet reached the well. The water extracted from the well must be frequently monitored since such water is used by the local population. The obtained results also indicate the necessity to drill wells for water monitoring and extraction around the gas station, in order to be able to dimension 


\section{Line SG_A-A'}

\section{Pseudo-section of observed apparent resistivity}

Iteration $=7$, error $=1.58 \%$

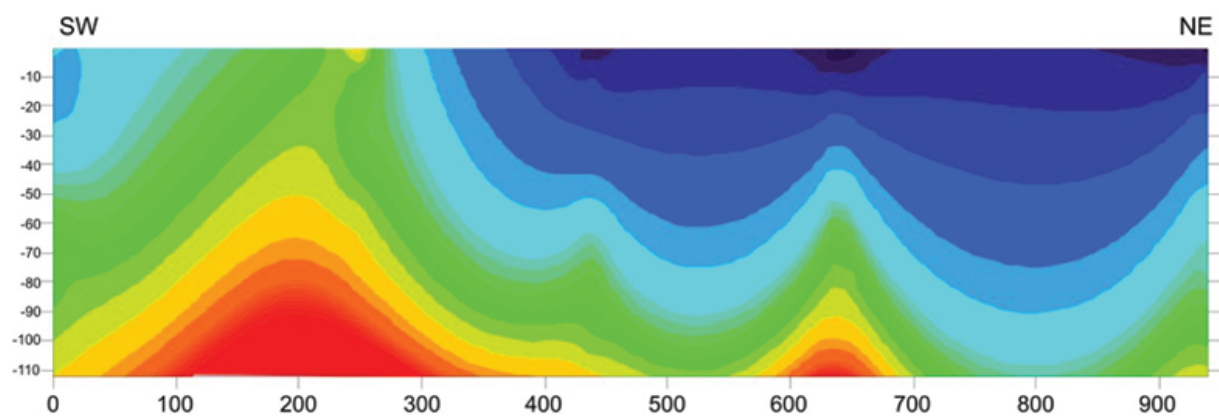

Pseudo-section of calculated apparent resistivity

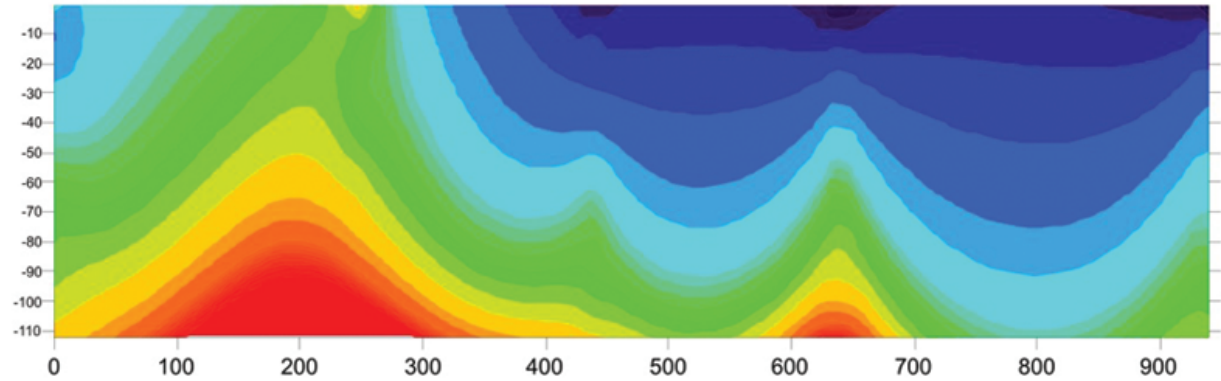

Resistivity section

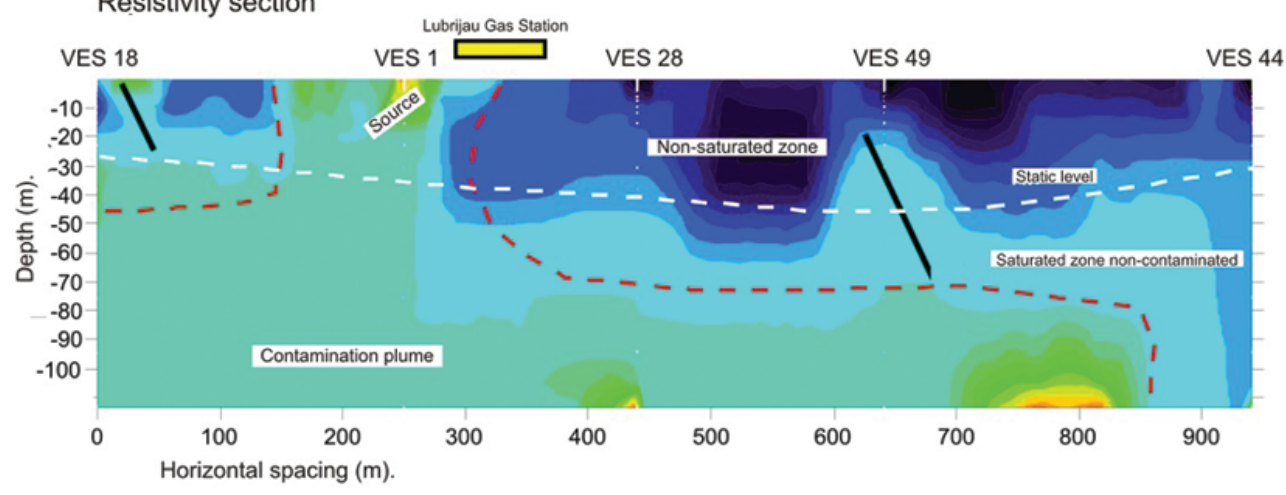

Resistivity (Ohm.m)

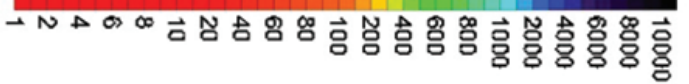

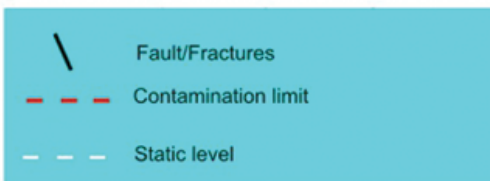

Figure 8 - Results of the 2D inversion of Line SG_A-A'.

the degree of contamination and to restrain the propagation of the plume, thus avoiding the risk of the population being contaminated through the use of such water.

In fact, prevention against contamination is the effective measure that should be applied, given that the remediation or recoup of the affected areas involve high costs. Therefore, the use and management of the groundwater deserve more attention from the authorities and from the population. Programs to promote the rational and sustainable use of hydric resources should be defined and multidisciplinary research should be conducted on the theme. From a scientific point of view, the results of this paper were important to sustain and promote studies on hydrogeologi- 
cal evaluation and on environmental contamination of the MarizalSão Sebastião aquifer system in Alagoinhas County, Bahia State.

\section{ACKNOWLEDGMENTS}

We thank CPGG/UFBA for offering the opportunity and the infrastructure for the development of this study, FAPESB for the advancement of a scholarship and CNPq for financing of the HydroIogic Evaluation and Environmental Contamination Survey of the Aquifers of the Northern Recôncavo, Bahia State, Project.

\section{REFERENCES}

ATEKWANA EA, SAUCK WA \& WERKEMA Jr DD. 2000. Investigations of geoelectrical signatures at a hydrocarbon contaminated site. Journal of Applied Geophysics, 44: 167-180.

GEOTOMO SOFTWARE. 2010. Geoelectrical Imaging 2D \& 3D: RES2DINV, ver. 3.59 for Windows XP/Vista/7. Rapid 2D Resistivity \& IP inversion using the least-squares method, Geotomo Software, Penang, Malaysia.

GHIGNONE JI. 1979. Geologia dos sedimentos fanerozóicos do Estado da Bahia. In: Geologia e Recursos Minerais do Estado da Bahia, Textos Básicos. SME/CPM: 23-117, Salvador.

G00GLE EARTH. 2010. Available on: <http://www.earth.google.com>. Access on: March 15, 2010.

KOEFOED 0. 1979. Geosounding principles: Resistivity sounding measurements. Elsevier, Amsterdam. 276 pp.

LIMA OAL. 1999. Caracterização hidráulica e padrões de poluição no aquífero Recôncavo na região de Camaçari-Dias D’Ávila. Tese Prof. Titular, Universidade Federal da Bahia, Instituto de Geociências, Salvador. $123 \mathrm{pp}$.
LIMA OAL, SATO HK \& PORSANI MJ. 1995. Imaging industrial contaminant plumes with resistivity techniques. Journal Applied Geophysics, 34(2): 93-108.

LOKE MH. 2001. 1-D Resistivity, IP \& SIP, Inversion and forward modeling, Wenner and Schlumberger arrays. User's Manual. 12 pp.

MANOEL FILHO J. 2008. Contaminação das águas subterrâneas. In: Hidrogeologia - Conceitos e Aplicações: 381-404, CPRM, LABHID, Rio de Janeiro.

NASCIMENTO SAM. 2005. Avaliação quantitativa e qualitativa dos recursos hídricos subterrâneos no município de Alagoinhas, Bahia. TECBAHIA, 20: 139-153.

PEREIRA PA \& LIMA OAL. 2007. Estrutura elétrica da contaminação hídrica provocada por fluidos provenientes dos depósitos de lixo urbano e de um curtume no município de Alagoinhas, Bahia. Revista Brasileira de Geofísica, 25(1): 5-19.

PORCIÚNCULA RJ. 2007. Aplicação do método eletrorresistivo na avaliação geoambiental da região de Alagoinhas, Bahia. Final Undergraduate Project in Geophysics, Universidade Federal da Bahia, Geosciences Institute, Salvador. 34 pp.

PORSANI JL, MALAGUTTI FILHO W, ELIS VR, FISSEHA S, DOURADO JC \& MOURA HP. 2004. The use of GPR and VES in delineating a contamination plume in a landfill site: a case study in SE Brazil. Journal of Applied Geophysics, 55: 199-209.

SAUCK WA, ATEKWANA EA \& NASH MS. 1998. High conductivities associated with an LNAPL plume imaged by integrated geophysical techniques. Journal of Environmental and Engineering Geophysics, 2(3): 203-212.

TELFORD WM, GELDART LP \& SHERIFF RE. 1990. Applied Geophysics. Cambridge University Press, Cambridge. 770 pp.

\section{NOTES ABOUT THE AUTHORS}

Rogério de Jesus Porciúncula. Graduated (2007) and Master (2011) in Geophysics at the Universidade Federal da Bahia (UFBA). Develops research on Hydrogeology and on Geophysics applied to geo-environmental studies. At present is employed by a company dedicated to environmental diagnosis and remediation of affected areas. Eventually renders consultancy services on Applied Geophysics.

Olivar Antônio Lima de Lima. Graduated (1967) and Master (1970) in Geology at Universidade Federal do Rio de Janeiro (UFRJ). Ph.D. in Geophysics (1979) at Universidade Federal da Bahia (UFBA). Post-doctor in Petrophysics (1989-1990) at the Texas University, Petroleum Engineering Department, Austin, TX, U.S.A. Senior Professor at Universidade Federal da Bahia (UFBA). Research fields include: the use of electric and electromagnetic methods in petroleum exploration, underground water surveys and environmental problems; physical properties of rocks and geophysical profiling of bore holes. Founding member of SBGf and active member of both SEG and EAGE. 